\title{
Памяти Дмитрия Олеговича Серова
}

\author{
Ольга Евгеньевна Кошелева \\ Институт всеобщей истории РАН \\ Ol'ga Evgen'evna Kosheleva \\ Institute of World History, Russian Academy of Sciences \\ okosheleva@mail.ru
}

Дмитрия Олеговича Серова больше нет с нами. Он так не хотел никаких некрологов, он хотел жить и работать, боролся со смертью долго, героически, до последнего вздоха, но 6 октября она его победила. Все! Теперь осталась только память. Возможно, она сильнее смерти.

Дмитрий Олегович родом из Новосибирска. В 1981 г. он поступил на Гуманитарный факультет Новосибирского Университета, где были прекрасные преподаватели и свободная атмосфера академического города. Тогда он видел себя филологом и закончил обучение по специальности “филология.” Дмитрий имел литературный дар, который проявлялся во всем, что бы он ни писал, даже в поздравительных открытках. В то время в Новосибирском университете работал академик Николай Николаевич Покровский (1930-2013) - опальный профессор, удаленный из Москвы в Сибирь, блестящий знаток древнерусской культуры и харизматическая личность. Участие в кружке Покровского во многом способствовало формированию интересов Дмитрия Олеговича.

В 1988 г. Дмитрий был зачислен в аспирантуру Ленинградского отделения Института истории (сейчас - Санкт-Петербургского института истории) и начал путь историка-исследователя. Его первым научным трудом стало изучение текста так называемой Юрьевской Степенной книги, созданной дьяком Иваном Юрьевым по заказу Петра Великого. Рукопись о Степенной, очень долго лежавшая в издательстве, вдруг вышла в свет в 2013 г., ${ }^{1}$ став приятной неожиданностью к 50-летию Дмитрия Олеговича. Работа с биографией Ивана Юрьева сформировала те главные исследовательские интересы, которые он реализовывал всю жизнь: увлечение петровским временем, его особой атмосферой сочетания старого с новым, его людьми, проживавшими свою жизнь в такое непростое время. Ровно в срок, в 1991 г. диссертация была защищена. Вырвавшись из рамок кандидатского дискурса, сковывавшего творческие порывы, Дмитрий Олегович на тех же материалах написал под влиянием бодрящего духа 90-х годов лучшую свою книгу, которая давно нуждается в переиздании - “Строители империи." окружавшие Петра, ожили, заговорили и, выйдя из тени царя-реформатора, стали действовать самостоятельно и строить Великую Империю, мало различая собственные и государственные интересы. Книга включала в себя множество новых

\footnotetext{
${ }^{1}$ Иван Юрьев, Известие о житии и действах державствующих великих князей российских, ред. Д. О. Серов (Москва: ОГИ, 2013). (Ivan Iur'ev, Izvestie o zhitii i deistvakh derzhavsnvuiushchikh velikikh kniazei rossiiskikh, red. D. O. Serov (Moscow: OGI, 2013)).

2 Д. О. Серов, Строители империи: очерки государственной и криминальной деятельности сподвижников Петра I (Новосибирск: Издательство Новосибирского университета, 1996). (D. O. Serov, Stroiteli imperii: ocherki gosudarstvennoi i kriminal'noi deiatel'nosti spodvizhnikov Petra I (Novosibirsk: Izdatel'stvo Novosibirskogo universiteta, 1996)).
} 
источников, немало открытий, и демонстрировала таланты автора - и писательский, и исследовательский.

В 1990-х Дмитрий вернулся в Сибирь и включился в деятельность по организации Университета экономики и управления в Новосибирске, читал в нем лекции, с 1999 г. до конца жизни руководил кафедрой теории и истории государства и права. Таким образом, Дмитрий Олегович начал работать с темой истории права. Он стал ведущим специалистом в области судебной и правоохранительной системы России, по-новому занялся историей следственных органов, выпустив изрядное количество книг и статей, посвященных следствию и следователям в России. Основными стали два историко-правовых исследования - о прокуратуре и о судебной реформе Петра. Тем не менее докторская диссертация, посвященная фискалам и прокуратуре в петровское время защищалась по специальности "История отечества."

Работая с судебной реформой Петра I, Дмитрий Олегович начинал с зарождения идей, показывал их развитие - от первых набросков и обсуждений до их воплощения в нормативных актах, а затем - прослеживал процесс реализации вводимых в жизнь новшеств, их историческую судьбу. Он был далек от абстрактных реконструкций государственной деятельности: им четко определялся круг лиц, причастных к данной реформе. Затем воссоздавались их биографии и характеры, их взаимоотношения и стили поведения. Он реконструировал конкретные обстоятельства, в которых эти люди действовали, все неожиданности и случайности, ошибки и удачи, сопровождавшие то или иное нововведение. В результате у Дмитрия Олеговича получалось “плотное описание" реформы и многоуровневое воссоздание исторической реальности. Невероятную сложность создания такого исследовательского нарратива может оценить только практикующий историк, который представляет себе весь колоссальный объем выявленных (зачастую впервые) документов, работу по их прочтению, атрибуции, сопоставлению, а также корректной интерпретации. Он каким-то невероятным образом знал даже неописанные материалы Сената и разбирался в неопубликованных бумагах Кабинета Петра. Для далеких от этой тематики людей, которые с легкостью и интересом читают тексты Д. О. Серова, вся эта исследовательская кухня остается за кадром, в этом умении просто и увлекательно писать о сложных вещах ярко проявлялось его профессиональное мастерство. Не последним компонентом в этом мастерстве была и фантастическая работоспособность Дмитрия Олеговича, он редко отвлекался от работы, и я просто не знаю, отдыхал ли он когда-нибудь.

Изучение начального этапа создания контрольно-надзорных органов в российской государственной системе до докторской диссертации Серова не казалось историкам и правоведам необходимым, поскольку опыт этого времени был полон проб и ошибок, а созданные институции достаточно быстро распались после смерти Петра. Однако Дмитрий Олегович опроверг такую скептическую точку зрения. Вопервых, он показал фундаментальные основы, заложенные в этом начальном опыте.

\footnotetext{
3 Д. О. Серов, Прокуратура Петра I (1722-1725 г2.): историко-правовой очерк (Новосибирск: Сибвузиздат, 2002); Серов, Судебная реформа Петра I: историко-правовое исследование (Москва: Зерцало-М, 2009); Серов, “Фискальская служба и прокуратура России первой трети XVIII в.” (Автореферат диссертации ... доктора исторических наук: Екатеринбург, 2010). (D. O. Serov, Prokuratura Petra I (1722-1725 gg.): istoriko-pravovoi ocherk (Novosibirsk: Sibvuzizdat, 2002); Serov, Sudebnaia reforma Petra I: istoriko-pravovoe issledovanie (Moscow: Zertsalo-M, 2009); Serov, "Fiksal'skaia sluzhba i prokuratura Rossii pervoi treti XVIII v." (Avtoreferat dissertatsii ... doktora istoricheskikh nauk: Ekaterinburg, 2010)).
} 
Во-вторых, он обозначил радикальный сдвиг в государственном сознании, который выразился в переходе от средневековой системы тайного контроля к контролю официальному и открытому, на основе законности и во благо общества. В фокусе исследователя оказался именно этот тонкий момент перехода - над боярами невозможно было поставить открытый контроль, они, как и сам царь, были подвластны только суду Божьему, в петровском же Сенате шло превращение бояр в чиновников, но контроль над ними работал еще плохо. В-третьих, на примере создания фискальской службы и прокуратуры Дмитрий Олегович показал возможности исторического изучения именно процесса сложного рождения реформы, а не только его результата.

Серов легко мог использовать профессиональный язык и понятийный аппарат правоведов, юридически осмысливать факты и события. Одновременно он анализировал исторический контекст, проделывал филигранную источниковедческую работу историка. В целом исследовательская манера Дмитрия Олеговича оказывается чрезвычайно редкой, если не уникальной. Дмитрий стремился представить каждый документ целиком, без купюр, и старался опубликовать его полностью в приложениях. При этом он умудрялся показать акты не в статике, а в динамике: то, как они видоизменялись в разных списках рукописей и в их публикациях.

Дмитрий Олегович регулярно ездил в Москву, чтобы работать в Архиве древних актов. Для него это было счастливое творческое время. Здесь, в читальном зале, мы с ним и познакомились в начале 1990-х. Знакомство вылилось в увлекательное общение по поводу тех событий и людей петровского времени, которые оживали на страницах архивных дел. Только сейчас, написав эти строки, я понимаю, что именно под влиянием Дмитрия Олеговича мой интерес переключился с XVII в. на петровский период истории, именно он показал мне перепись Петербургского острова 1718 г., с которой началась моя будущая книга и диссертация. Нас сближало пристрастие к восстановлению биографий людей того времени, к виртуальному контакту с ними. Помню, как Дмитрий Олегович позвонил мне из телефонаавтомата в аэропорту, улетая в Новосибирск: "У меня секунда времени. Хочу сообщить, что мне в документе попался отец такого-то подьячего. Теперь понятно, какого он происхождения! Все, побежал!”. Он сообщил об этом так срочно не потому, что это было важно - совсем нет!, а потому, что это было нам интересно: любопытен и необъясним был быстрый карьерный рост этого подьячего. Дмитрия Олеговича вообще интересовал этот аспект - как люди в петровское время делали карьеру, поднимались наверх из самых низких чинов. Это было время риска и открытых возможностей, оно резонировало с 1990-ми и тем оказывалось вдвойне увлекательным.

Дмитрий Олегович настолько вжился в житье-бытье петровского времени, что придумал своего литературного героя - пушкаря из Тотьмы Кузьму Фомича Хахарина, эпизоды (“анекдоты”) из жизни которого с юмором и очень тонкой стилизацией под язык петровской эпохи поведал современному читателю. Некоторые историки даже попадались на удочку, принимая его “анекдоты" за текст XVIII в. Этот редчайший жанр литературной стилизации, как это ни странно, стал препятствием для публикации книги о Хахарине, написанной еще в 1990-ые. Издательства возвращали ее, ибо она не вписывалась ни в какую серию, ни в какой жанр - была совершенно уникальна. И только через много лет, в 2013 г., книга "Куриозные гистории о днех жизни Кузьмы Фомича Хахарина, Тотемского горнизона Генерального пушкаря, еже содеялись в государствование всемилостивейшего 
монарха ПЕТРА ВЕЛИКОГО" была издана в Новосибирске к 5о-летию Дмитрия Олеговича его родными. Туда вошли далеко не все им написанные тексты в жанре литературной стилизации. Надеюсь, что они еще будут изданы, а Хахарин переиздан, так как эта книга мало доступна и практически незнакома широкому кругу читателей.

Неординарным проектом Д. О. Серова двухтысячных годов было возвращение из небытия трудов Н. А. Воскресенского (1889-1948), историка, публикацией источников которого “Законодательные акты Петра I" (Ленинград, 1945 г.) исследователи продолжают активно пользоваться и по сей день, однако мало кто знал, кто это такой. Более это имя нигде не встречалось. В свое время Воскресенский был отвергнут как исследователь академическим сообществом историков, ибо являлся всего лишь школьным учителем. Дмитрию Олеговичу оказалась близка тематика, которой занимался Воскресенский, но главным образом его заинтересовала судьба этого человека, которому он глубоко сочувствовал, называл “подвижником" и по отношению к которому хотел восстановить справедливость. Он по крупицам собрал его биографию ${ }^{4}$ и опубликовал его несколько устаревший, но во многом непревзойденный труд, ${ }^{5}$ искупив за всех вину перед ним. Вторая часть работы Воскресенского не успела выйти при жизни Дмитрия Олеговича, ее завершает И. И. Федюкин.

Незаконченных начинаний Серова осталось много - главным, видимо, была книга про Прутский поход, которая уже получила определенные очертания. Обсуждали исследование о взяточничестве, писавшееся в соавторстве с Д. А. Рединым.

Дмитрий Олегович всегда одевался в черное, но был очень светлым человеком, чрезвычайно отзывчивым и открытым. Он всегда щедро делился и знаниями, и архивными находками, интересовался работой и успехами коллег, искренне за всех радовался и печалился, помогал чем мог. И московская, и петербургская, и екатеринбургская научная жизнь была и его жизнью. Без него она трагически обеднела.

\footnotetext{
${ }^{4}$ Д. О. Серов, “Н. А. Воскресенский (1889-1948)- Подвижник науки истории русского права," в Петр Великий как законодатель. Исследование законодательного процесса в России в эпоху реформ первой четверти XVIII века, ред. Н. А. Воскресенский (Москва: Новое литературное обозрение, 2017). (D. О. Serov, "N. A. Voskresenskii (1889-1948)- Podvizhnik nauki istorii russkogo prava," v Petr Velikii kak zakonodatel'. Issledovanie zakonodatel'nogo protsessa v Rossii v epokhu reform pervoi chetverti XVIII veka, red. N. A. Voskresenskii (Moscow: Novoe literaturnoe obozrenie, 2017)). D. O. Serov, "Dramatic Destiny of Nikolai Voskresenskiy, a Russian Law Historian," Quaestio Rossica 1 (2014): 221-240.

${ }^{5}$ Воскресенский, Петр Великий как законодатель. (Voskresenskii, Petr Velikii kak zakonodatel').
} 